\title{
Literature Review : Gambaran Perilaku Hidup Bersih dan Sehat Masyarakat di Masa Pandemi Covid-19
}

\author{
Rizki Amaliyah1*, Neti Mustikawati2 \\ 1,2 Program Studi Sarjana Keperawatan, Universitas Muhammadiyah Pekajangan Pekalongan, \\ Indonesia \\ *email : rizkiamaliyah2709@gmail.com
}

\begin{abstract}
The spread of COVID-19 is rampant. Every individual is at risk of being infected and transmitted. Hygiene Behavior and Healthy Lifestyle are recommended to prevent COVID-19 infection. This study aims to describe hygiene behavior and a healthy lifestyle (washing hands, physical activity, consumption of fruits and vegetables, wearing mask, social distance) during the COVID-19 pandemic. This research is a literature review research. The subjects of this study were people aged over 16 years. The method used is to search for articles ranging from 2019-2021, through a database in the form of PubMed using the keywords "Health behavior" AND "Coronavirus Disease 2019" AND "public" and Google Scholar using the keywords "Clean and Healthy Living Behavior in the Community during the Covid pandemic. $19^{\prime \prime}$ then assessed using a hawker. Five articles were indentified. The findings highlight the hand washing behaviour during the Covid-19 pandemic: 5,329 $(82.5 \%)$ always hand wash with soap and water, $38(35.3 \%)$ often apply six steps wash their hands, $59(83.1 \%)$ always hand wash with soap and water after leaving the house, $54(76.1 \%)$ always hand wash with soap and water before eating, $35(49.3 \%)$ always hand wash with soap and water after holding money, and 142 (39.6\%) wash their hands before touching food. The physical activity during the COVID-19 pandemic: 41 (38\%) rarely, 199 (55.1\%) 150 minutes/week, and $3,960(73.8 \%)$ less than three times in a week. Fruits \& vegetables consumption during the COVID-19 pandmic: 3,309 (49.7\%) sometimes, $96(50.26 \%)$ sometimes, and 289 $(80.0 \%)$ consume fruits \& vegetables. The use of masks during the COVID-19 pandemic: 102 (57\%) always, and $188(98.4 \%)$ using masks. Meanwhile, social distancing during the COVID-19 pandemic is $37(8.6 \%)$ never, $6(1.3 \%)$ sometimes, $34(8.0 \%)$ and always 355 $(82.1 \%)$. People have hygiene behavior and a healthy lifestyle to minimize the transmission of COVID-19.
\end{abstract}

Keywords :COVID-19, Community, PHBS.

\section{Abstrak}

PenyebaranCovid-19semakin tidak terkendali, setiap individu resiko tertular dan menularkan. Perilaku Hidup Bersih dan Sehat (PHBS) di anjurkan pemerintah sebagai pencegahan Covid19. Penelitian ini bertujuan untuk mengetahui gambaran PHBS (Cuci tangan, aktivitas fisik, konsumsi buah dan sayur, memakai masker, menjaga jarak)masyarakat di masa pandemi Covid-19. Penelitian ini merupakan pennelitian literature review. Subjek penelitian ini masyarakat yang berumur diatas 16 tahun. Metode yang digunakan yaitu mencari artikel rentang tahun 2019-2021, melalui database berupa PubMed menggunakan kata kunci "Health behavior" AND "Coronavirus Disease 2019" AND "public" dan Google Scholar menggunakan kata kunci "Perilaku Hidup Bersih dan Sehat Masyarakat di masa pandemi Covid-19" lalu di nilai menggunakan hawker. Hasil penelitian literature review dari 5 artikel menunjukkan bahwa cuci tangan masyarakat di masa pandemi Covid-19: 5.329 $(82,5 \%)$ selalu CTPS, $38(35,3 \%)$ sering cuci tangan 6 langkah, $59(83,1 \%)$ selalu CTPS setelah keluar rumah, $54(76,1 \%)$ selalu CTPS sebelum makan, $35(49,3 \%)$ selalu CTPS setelah memegang uang, dan $142(39,6 \%)$ cuci tangan sebelum menyentuh makanan.Aktivitas fisik masyarakat di masa pandemi Covid-19 : 41 (38\%) jarang, 199 $(55,1 \%)$ 150menit/minggu, dan $3.960(73,8 \%)<3 X$ seminggu.Konsumsi buah \& sayur 


\section{Prosiding Seminar Nasional Kesehatan Lembaga Penelitian dan Pengabdian Masyarakat Universitas Muhammadiyah Pekajangan Pekalongan}

masyarakat di masa pandemi Covid-19:3.309 (49,7\%) kadang-kadang, 96 (50,26\%) kadang-kadang, dan $289(80,0 \%)$ mengkonsumsi buah \& sayur. Penggunaan masker masyarakat di masa pandemi Covid-19 : 102 (57\%) selalu, dan $188(98,4 \%)$ menggunakan masker. Sedangkan jaga jarak masyarakat di masa pandemi Covid-19 yaitu $37(8,6 \%)$ tidak pernah, $6(1,3 \%)$ kadang-kadang, $34(8,0 \%)$ dan selalu 355 (82,1\%). PHBS sudah dilakukan masyarakat untuk meminimalisir penularan Covid-19.

Kata Kunci :Covid-19, Masyarakat, PHBS.

\section{Pendahuluan}

Coronavirus Disease 2019 merupakan penyakit menular yang disebabkan oleh SARS-CoV-2 atau Severe Acute Respiratory Syndrome Coronavirus 2. Sedangkan Servere Acute Respiratory Syndrome Coronavirus 2 itu sendiri merupakan coronavirus jenis baru yang belum pernah ditemukan sebelumnya pada manusia. Midle East Respiratory Syndrome serta Severe Acute Respiratory Syndrome merupakan 2 jenis Corona Virus Disease 2019 yang menyebabkan penyakit dan menimbulkan gejalagejala berat. Gangguan pernapasan akut, suhu badan tinggi, batuk serta sesak napas merupakan manisfestasi klinis umum infeksi COVID-19. Masa inkubasi COVID-19 ratarata 5 sampai 6 hari dengan masa inkubasi terpanjang 14 hari. Coronavirus yang berat dapat menyebabkan sindrom pernapasan akut, pneumonia, gagal ginjal, bahkan bisa menyebabkan kematian. (Sugihantono, A., Burhan,E.dkk.2020).

Kasus pneumonia yang tidak diketahui etiologinya dilaporkan oleh WHO china Country Office pada tanggal 31 Desember 2020 di Kota Wuhan, Provinsi Hubei, Cina. China pada tanggal 7 Januari 2020 mengidentifikasi kasus tersebut sebagai jenis baru coronavirus. Pada tanggal 30 Januari 2020 WHO menetapkan kasus coronavirus sebagai Kedaruratan Kesehatan Masyarakat yang Meresahkan Dunia (KKMMD)/Public Health Emergency of International Concern (PHEIC). WHO menetapkan COVID-19 sebagai pandemic pada tanggal 11 Maret 2020. Jumlah kasus meningkat berlangsung cukup cepat, dan menyebar ke berbagai negara termasuk Indonesia dalam waktu singkat.Indonesia melaporkan kasus pertama pada tanggal 2 Maret 2020.(Sugihantono, A., Burhan, E. dkk.2020). Kasus meningkat dan menyebar dengan cepat di seluruh wilayah Indonesia. Sampai dengan tanggal 18 Febuari 2021 Kementrian Kesehatan Republik Indonesia melaporkan terdapat 1,252,685 kasus konfirmasi , 33,969 meninggal , dan 1,058,222 sembuh (Kemenkes RI.2021).

Penularan COVID-19 terjadi melalui droplet yang dapat menginfeksi manusia dengan masuknya droplet yang mengandung virus SARS-CoV-2 ke dalam tubuh area segitiga wajah. COVID-19 dapat dicegah dengan mencegah masuknya virus melalui ketiga pintu masuk tersebut dengan beberapa tindakan, seperti menggunakan APD berupa masker yang menutupi hidung, mulut hingga dagu.COVID-19 juga dapat dicegah dengan cuci tangan dengan sabun dan air mengalir bisa juga menggunakan handsanitizer. Menjaga jarak minimal 1 meter dengan orang lain untuk mencegah terkena droplet. Menghindari kerumunan serta meningkatkan daya tahan tubuh dengan menerapkan Perilaku Hidup Bersih dan Sehat atau PHBS seperti mengkonsumsi buah dan sayur atau gizi seimbang, aktivitas fisik minimal 30 menit sehari serta istirahat yang cukup minimal 7 jam sehari.(Kemenkes. 2020).

Dalam memutus mata rantai penularan COVID-19 masyarakat menjadi peran penting, supaya tidak menimbulkan cluster atau sumber penularan baru pada tempat- 


\section{Prosiding Seminar Nasional Kesehatan Lembaga Penelitian dan Pengabdian Masyarakat Universitas Muhammadiyah Pekajangan Pekalongan}

tempat dimana terjadinya pergerakan orang, interaksi antar manusia serta berkumpulnya banyak orang. Kebiasaan baru yang lebih sehat, lebih bersih, serta lebih patuh, yang dilaksanakan oleh seluruh kalangan yang ada di masyarakat serta memberdayakan semua sumber daya yang ada, merupakan beberapa cara masyarakat beraktivitas dalam situasi pandemi COVID-19 ( Keputusan Menteri Kesehatan Republik Indonesia. 2020 )

Menurut Menteri Kesehatan Republik Indonesia dalam Pedoman Pembinaan Perilaku Hidup Bersih dan Sehat, PHBS merupakan sekumpulan perilaku yang dilakukan atas dasar kesadaran, serta menjadikan seseorang, keluarga, kelompok atau masyarakat dapat menolong dirinya sendiri di bidang kesehatan serta ikut serta dalam mewujudkan kesehatan masyarakat ( Peraturan Menteri Kesehatan Republik Indonesia. 2011 )

Menurut Dinas Kesehatan Sleman. 2020, cara efektif untuk mencegah COVID-19 dengan menerapkan PHBS seperti makan bergizi, olah raga teratur, mencuci tangan, menghindari menyentuh wajah, memakai masker, istirahat yang cukup, menerapkan etika batuk dan bersin, menjaga kebersihan lingkungan, meghindari kerumunan, serta menjaga jarak aman.

Berdasarkan hasil penelitian dari Karuniawati B. \& Putrianti, B. 2020, yang berjudul Gambaran Perilaku Hidup Bersih dan Sehat (PHBS) dalam Pencegahan Penularan COVID-19. Penelitian dilakukan dari bulan Febuari sampai Juni 2020, terdapat 83,1\% selalu mencuci tangan, memakai masker sebanyak $95,8 \%$, sudah jaga jarak sebanyak $47,9 \%$, menyediakan makanan sehat untuk keluarga $71,8 \%$, Simpulan dari penelitian tersebut yaitu masyarakat saat ini sudah sangat sadar dengan PHBS, dan masyarakat sudah menerapkan PHBS dengan baik.

Berdasarkan latar belakang tersebut maka peneliti tertarik untuk melakukan penelitian dengan judul literature review : gambaran perilaku hidup bersih dan sehat masyarakat di masa pandemi covid-19.

\section{Literature Review}

Literature review berisi diskusi pengetahuan tentang topik yang sedang dipelajari untukmemperkuatgagasanriset.

\section{Metode}

Penelitian ini merupakan penelitian literature review dan subjek penelitian ini adalah masyarakat berumur diatas 16 tahun. Dalam penelitian ini menggunakan data sekunder. Data yang digunakan tidak langsung terjun secara langsung, melainkan mengambil data dari penelitian terdahulu yang sudah pernah dilaksanakan. Sumber database yang digunakan dalam penelitian ini yaitu PubMed dan Google Scholar yang berupa artikel.Artikel yang dianalisa diberi batasan dari 2019-2021,Peneliti membuka web https://pubmed.ncbi.nlm.nih.gov/ kemudian menuliskan kata kunci "Health behavior" AND "Coronavirus Disease 2019" AND "public" didapatkan 35.536 artikel. Kemudian artikel di identifikasi melalui judul didapatkan 10.400. Lalu artikel di identifikasi melalui abstrak didapatkan 2 artikel. Kemudian artikel di identifikasi lagi berdasarkan kriteria inklusi dan ekslusi didapatkan 1 artikel. Peneliti juga membuka web https://scholar.google.com/ kemudian menuliskan kata kunci "Perilaku Hidup 


\section{Prosiding Seminar Nasional Kesehatan Lembaga Penelitian dan Pengabdian Masyarakat Universitas Muhammadiyah Pekajangan Pekalongan}

Bersih dan Sehat Masyarakat di masa pandemi Covid-19" didapatkan 265 artikel. Artikel di identifikasi melalui judul didapatkan 265 artikel. Lalu artikel di identifikasi lagi melalui abstrak di dapatkan 6 artikel. Kemudian artikel di identifikasi lagi berdasarkan kriteria inklusi antara lain Perilaku Hidup Bersih dan Sehat di masa pandemi Covid-19, gaya hidup sehat di masa pandemi Covid-19, artikel yang sesuai dengan kata kunci, ditulis dalam bahasa Indonesia dan bahasa Inggris, artikel atau jurnal penelitian terbit tahun 2019 sampai 2021, masyarakat yang berumur diatas 16 tahun. Sedangkan kriteria ekslusi antara lain study desigh systematic / literature review, artikel tidak full text, artikel dengan metode penelitian kualitatifmaka di dapatkan 4 artikel. Kemudian artikel di nilai menggunakan Hawker sehingga didapatkan 5 artikel dalam bentuk fullext dan format Pdf.

\section{Hasil dan Pembahasan Hasil}

Hasil analisa data pada penelitian literature review adalah sebagai berikut :

1. Karakteristik responden

Tabel 4.1 Hasil Analisis Literature RevienKarakteristik Responden berdasarkan Usia

\begin{tabular}{|c|c|c|c|c|c|c|c|c|}
\hline \multicolumn{3}{|c|}{ Artikel } & \multicolumn{6}{|c|}{ Usia } \\
\hline \multirow[t]{2}{*}{ No } & \multirow[t]{2}{*}{ Penulis } & \multirow{2}{*}{$\begin{array}{c}\text { Tahu } \\
\mathrm{n}\end{array}$} & \multicolumn{2}{|c|}{$<20$ tahun } & \multicolumn{2}{|c|}{ 20-35 tahun } & \multicolumn{2}{|c|}{$>35$ tahun } \\
\hline & & & $\mathrm{F}$ & $\%$ & $\mathrm{~F}$ & $\%$ & $\mathrm{~F}$ & $\%$ \\
\hline 1 & $\begin{array}{l}\text { Karuniawati, B \& } \\
\text { Putrianti, B }\end{array}$ & 2020 & 1 & 1,4 & 37 & 52,1 & 33 & 46,5 \\
\hline 2 & Utama, L. T & 2020 & 40 & 20.94 & 116 & 60,73 & 35 & 18,32 \\
\hline 3 & $\begin{array}{l}\text { Atmaja, T. F. A., } \\
\text { et al }\end{array}$ & 2020 & NM & NM & NM & NM & $\begin{array}{l}N \\
M\end{array}$ & NM \\
\hline 4 & $\begin{array}{l}\text { Tejoyuwono, A. } \\
\text { A. T., et al }\end{array}$ & 2020 & NM & NM & NM & NM & $\begin{array}{l}\mathrm{N} \\
\mathrm{M}\end{array}$ & NM \\
\hline 5 & Putri, R. M., et al & 2020 & 11 & 10.2 & 96 & 88,9 & 1 & 9 \\
\hline Tot: & masing-masing us & & 52 & 14 & 249 & 67,3 & $\begin{array}{l}6 \\
9\end{array}$ & 18,7 \\
\hline
\end{tabular}

Berdasarkan hasil literatur review terhadap 5 artikel didapatkan karakteristik responden berdasarkan usia (Table 4.1 ) didapatkan hasil 52 (14\%) yaitu usia $<20$ tahun tahun, $249(67,3)$ yaitu usia $20-35$ tahun dan $69(18,7)$ yaitu usia >35 tahun. Berdasarkan tabel di atas responden berdasarkan usia yang lebih banyak yaitu rentang usia 20-35 tahun. 


\section{Prosiding Seminar Nasional Kesehatan Lembaga Penelitian dan Pengabdian Masyarakat Universitas Muhammadiyah Pekajangan Pekalongan}

Tabel 4.2 Hasil Analisi Literature Review Karakteristik Responden berdasarkan Jenis Kelamin

\begin{tabular}{|c|c|c|c|c|c|c|}
\hline \multicolumn{3}{|c|}{ Artikel } & \multicolumn{4}{|c|}{ Jenis kelamin } \\
\hline \multirow[t]{2}{*}{ No } & \multirow[t]{2}{*}{ Penulis } & \multirow[t]{2}{*}{ Tahun } & \multicolumn{2}{|c|}{ Laki-laki } & \multicolumn{2}{|c|}{ Perempuan } \\
\hline & & & $\mathrm{F}$ & $\%$ & $F$ & $\%$ \\
\hline 1 & $\begin{array}{l}\text { Karuniawati, B \& } \\
\text { Putrianti, B }\end{array}$ & 2020 & NM & NM & NM & NM \\
\hline 2 & Utama, L. T & 2020 & 45 & 0,7 & 146 & 2,0 \\
\hline 3 & $\begin{array}{l}\text { Atmaja, T. F. A., } \\
\text { et al }\end{array}$ & 2020 & 1.620 & 22,4 & 4.937 & 68,4 \\
\hline 4 & $\begin{array}{l}\text { Tejoyuwono, A. } \\
\text { A. T., et al }\end{array}$ & 2020 & 267 & 3,7 & 94 & 1,3 \\
\hline 5 & Putri, R. M., et al & 2020 & 36 & 0,5 & 72 & 1 \\
\hline \multicolumn{3}{|c|}{$\begin{array}{l}\text { Total masing-masing jenis } \\
\text { kelamin }\end{array}$} & 1.968 & 27,3 & 5.249 & 72,7 \\
\hline \multicolumn{3}{|c|}{ Total responden } & \multicolumn{4}{|c|}{7.217} \\
\hline
\end{tabular}

Berdasarkan hasil literature review karakteristik responden berdasarkan jenis kelamin (Table 4.2) didapatkan hasil 1.968 (27,3\%) yaitu responden berjenis kelamin laki-laki dan $5.249(72,7 \%)$ yaitu responden berjenis kelamin perempuan. Berdasarkan tabel di atas responden dominan berjenis kelamin perempuan lebih banyak dari responden yang berjenis kelamin laki-laki.

Tabel 4.3 Hasil Analisis Literature Review Karakteristik Responden berdasarkan Pendidikan

\begin{tabular}{|c|c|c|c|c|c|c|c|c|}
\hline \multicolumn{3}{|c|}{ Artikel } & \multicolumn{6}{|c|}{ Pendidikan } \\
\hline \multirow[t]{2}{*}{ No } & \multirow[t]{2}{*}{ Penulis } & \multirow[t]{2}{*}{$\begin{array}{c}\text { Tahu } \\
\mathrm{n}\end{array}$} & \multicolumn{2}{|c|}{ SMP } & \multicolumn{2}{|c|}{ SMA } & \multicolumn{2}{|c|}{$\begin{array}{c}\text { Perguruan } \\
\text { Tinggi }\end{array}$} \\
\hline & & & $\mathrm{F}$ & $\%$ & $F$ & $\%$ & $\mathrm{~F}$ & $\%$ \\
\hline 1 & $\begin{array}{l}\text { Karuniawati, B } \\
\text { \& Putrianti, B }\end{array}$ & 2020 & 2 & 0,1 & 3 & 6,9 & 56 & 2 \\
\hline 2 & Utama, L. T & 2020 & 41 & 0,9 & 41 & 93,1 & 109 & 3,8 \\
\hline 3 & $\begin{array}{l}\text { Atmaja, T. F. } \\
\text { A., et al }\end{array}$ & 2020 & 4.351 & 99,0 & NM & NM & 2.206 & 77,6 \\
\hline 4 & $\begin{array}{l}\text { Tejoyuwono, A. } \\
\text { A. T., et al }\end{array}$ & 2020 & NM & NM & NM & NM & 361 & 12,7 \\
\hline 5 & $\begin{array}{l}\text { Putri, R. M., et } \\
\text { al }\end{array}$ & 2020 & NM & NM & NM & NM & 110 & 3,9 \\
\hline & $\begin{array}{l}\text { Total masing-mas } \\
\text { pendidikan }\end{array}$ & & 4.394 & 60,4 & 44 & 0,6 & 2.842 & 39,0 \\
\hline & Total responde & & & & & 80 & & \\
\hline
\end{tabular}

Berdasarkan hasil literatur review terhadap 5 artikel didapatkan karakteristik responden berdasarkan pendidikan (Tabel 4.3) didapatkan hasil $4.394(60,4)$ 


\section{Prosiding Seminar Nasional Kesehatan \\ Lembaga Penelitian dan Pengabdian Masyarakat Universitas Muhammadiyah Pekajangan Pekalongan}

yaitu pendidikan SMP, $44(0,6)$ yaitu pendidikan SMA dan $2.842(39,0)$ pendidikan perguruan tinggi. Berdasarkan tabel di atas, karakteristik kategori pendidikan yang lebih banyak yaitu pendidikan SMP.

2. Cuci tangan masyarakat di masa pandemi Covid-19

Tabel 4.4 Hasil Analisis Literature Review Cuci Tangan Pakai Sabun

\begin{tabular}{|c|c|c|c|c|c|c|c|c|c|c|c|c|}
\hline \multicolumn{3}{|c|}{ Artikel } & \multicolumn{10}{|c|}{ Cuci tangan pakai sabun } \\
\hline \multirow[t]{2}{*}{ No } & \multirow[t]{2}{*}{ Penulis } & \multirow[t]{2}{*}{ Tahun } & \multicolumn{2}{|c|}{$\begin{array}{c}\text { Tidak } \\
\text { pernah }\end{array}$} & \multicolumn{2}{|c|}{ Jarang } & \multicolumn{2}{|c|}{$\begin{array}{l}\text { Kadang- } \\
\text { kadang }\end{array}$} & \multicolumn{2}{|c|}{ Sering } & \multicolumn{2}{|c|}{ Selalu } \\
\hline & & & $\mathrm{F}$ & $\%$ & $F$ & $\%$ & $\mathrm{~F}$ & $\%$ & $F$ & $\%$ & $\mathrm{~F}$ & $\%$ \\
\hline 1 & Utama, L. T & 2020 & NM & NM & 2 & 0,03 & 26 & 0,4 & NM & NM & 163 & 2,6 \\
\hline 2 & $\begin{array}{l}\text { Atmaja, T. } \\
\text { F. A., et al }\end{array}$ & 2020 & 6 & 0.10 & 65 & 1,0 & 975 & 15,1 & NM & NM & 5.111 & 79,1 \\
\hline 3 & $\begin{array}{l}\text { Putri,R. M., } \\
\text { et al }\end{array}$ & 2020 & NM & NM & 18 & 0,27 & NM & NM & 35 & 0,5 & 55 & 0,9 \\
\hline \multicolumn{3}{|c|}{$\begin{array}{l}\text { Total masing-masing cuci } \\
\text { tangan pakai sabun }\end{array}$} & 6 & 0,10 & 85 & 1,3 & 1.001 & 15,6 & 35 & 0,5 & 5.329 & 82,5 \\
\hline \multicolumn{3}{|c|}{ Total responden } & \multicolumn{10}{|c|}{6.456} \\
\hline
\end{tabular}

Berdasarkan (Tabel 4.4) didapatkan bahwa tidak pernah $6(0,10)$, jarang 85 $(1,3)$, kadang-kadang $1.001(15,6)$, sering $35(0,5)$ dan $5.329(82,5)$ selalu mencuci tangan pakai sabun.

Tabel 4.5 Hasil Analisis Literature Review Cuci Tangan Dengan 6 Langkah

\begin{tabular}{|c|c|c|c|c|c|c|c|c|}
\hline \multicolumn{3}{|c|}{ Artikel } & \multicolumn{6}{|c|}{ Cuci tangan dengan 6 langkah } \\
\hline \multirow[t]{2}{*}{ No } & \multirow[t]{2}{*}{ Penulis } & \multirow[t]{2}{*}{ Tahun } & \multicolumn{2}{|c|}{ Jarang } & \multicolumn{2}{|c|}{ Sering } & \multicolumn{2}{|c|}{ Selalu } \\
\hline & & & $\mathrm{F}$ & $\%$ & $\mathrm{~F}$ & $\%$ & $\mathrm{~F}$ & $\%$ \\
\hline 1 & $\begin{array}{c}\text { Putri, R. M., et } \\
\text { al }\end{array}$ & 2020 & 33 & 30,6 & 38 & 35,3 & 37 & 34,3 \\
\hline \multicolumn{3}{|c|}{ Total responden } & \multicolumn{6}{|c|}{108} \\
\hline
\end{tabular}

Berdasarkan (Tabel 4.5) didapatkan bahwa jarang $33(30,6)$, sering 38 $(35,3)$ dan $37(34,3)$ selalu mencuci tangan dengan 6 langkah.

Tabel 4.6 Hasil Analisis Literature Review Cuci Tangan Menggunakan Sabun Setelah Keluar Rumah

\begin{tabular}{|c|c|c|c|c|c|c|}
\hline \multicolumn{3}{|c|}{ Artikel } & \multicolumn{4}{|c|}{ Cuci tangan menggunakan sabun setelah keluar rumah } \\
\hline \multirow[t]{2}{*}{ No } & \multirow[t]{2}{*}{ Penulis } & \multirow[t]{2}{*}{ Tahun } & \multicolumn{2}{|c|}{ Sering } & \multicolumn{2}{|c|}{ Selalu } \\
\hline & & & $\mathrm{F}$ & $\%$ & $\mathrm{~F}$ & $\%$ \\
\hline 1 & $\begin{array}{c}\text { Karuniawati, } \\
\text { B., Putrianti, } \\
\text { B }\end{array}$ & 2020 & 12 & 16,9 & 59 & 83,1 \\
\hline & Total respon & & & & & \\
\hline
\end{tabular}




\section{Prosiding Seminar Nasional Kesehatan \\ Lembaga Penelitian dan Pengabdian Masyarakat Universitas Muhammadiyah Pekajangan Pekalongan}

Berdasarkan (Tabel 4.6) didapatkan bahwa sering $12(16,9)$ dan $59(83,1)$ selalu mencuci tangan pakai sabun setelah keluar rumah.

Tabel 4.7 Hasil Analisis Literature Review Cuci Tangan dengan Menggunakan Sabun Sebelum Makan

\begin{tabular}{|c|c|c|c|c|c|c|c|c|}
\hline \multicolumn{3}{|c|}{ Artikel } & \multicolumn{6}{|c|}{ Cuci tangan dengan menggunakan sabun sebelum makan } \\
\hline \multirow[t]{2}{*}{ No } & \multirow[t]{2}{*}{ Penulis } & \multirow[t]{2}{*}{ Tahun } & $\mathrm{Kac}$ & dang & \multicolumn{2}{|c|}{ Sering } & \multicolumn{2}{|c|}{ Selalu } \\
\hline & & & $\mathrm{F}$ & $\%$ & $\mathrm{~F}$ & $\%$ & $\mathrm{~F}$ & $\%$ \\
\hline 1 & $\begin{array}{l}\text { Karuniawati, } \\
\text { B., Putrianti, } \\
\text { B }\end{array}$ & 2020 & 1 & 2,8 & 16 & 23,9 & 54 & 76,1 \\
\hline & Total responc & & & & & & & \\
\hline
\end{tabular}

Berdasarkan (Tabel 4.7) didapatkan bahwa kadang-kadang $1(2,8)$, sering $16(23,9)$ dan $54(76,1)$ selalu cuci tangan dengan menggunakan sabun sebelum makan.

Tabel 4.8 Hasil Analisis Literature Review Cuci Tangan dengan Menggunakan Sabun Setelah Memegang Uang

\begin{tabular}{|c|c|c|c|c|c|c|c|c|c|c|}
\hline \multicolumn{3}{|c|}{ Artikel } & \multicolumn{8}{|c|}{$\begin{array}{c}\text { Cuci tangan dengan menggunakan sabun setelah } \\
\text { memegang uang }\end{array}$} \\
\hline \multirow[t]{2}{*}{ No } & \multirow[t]{2}{*}{ Penulis } & \multirow[t]{2}{*}{ Tahun } & \multicolumn{2}{|c|}{ Tidak Pernah } & \multicolumn{2}{|c|}{$\begin{array}{l}\text { Kadang- } \\
\text { kadang }\end{array}$} & \multicolumn{2}{|c|}{ Sering } & \multicolumn{2}{|c|}{ Selalu } \\
\hline & & & $\mathrm{F}$ & $\%$ & $\mathrm{~F}$ & $\%$ & $\mathrm{~F}$ & $\%$ & $\mathrm{~F}$ & $\%$ \\
\hline 1 & $\begin{array}{l}\text { Karuniawati, } \\
\text { B., Putrianti, } \\
\text { B }\end{array}$ & 2020 & 0 & 0,0 & 9 & 12,7 & 27 & 38,0 & 35 & 49,3 \\
\hline & Total responc & & & & & 7 & & & & \\
\hline
\end{tabular}

Berdasarkan (Tabel 4.8) didapatkan bahwa tidak pernah $0(0,0)$, kadangkadang $9(12,7)$, sering $27(38,0)$ dan $35(49,3)$ selalu cuci tangan menggunakan sabun setelah memegang uang.

Tabel 4.9 Hasil Analisis Literature Review Kebiasaan Cuci Tangan Selama Pandemi Covid-19

\begin{tabular}{|c|c|c|c|c|c|c|c|c|c|c|c|c|c|c|c|}
\hline No & Penulis & Tahun & 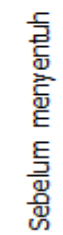 & 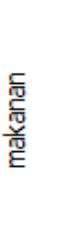 & 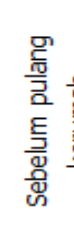 & & 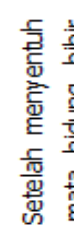 & & 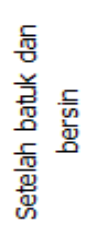 & 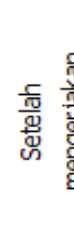 & 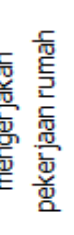 & & 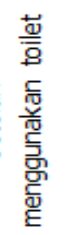 & 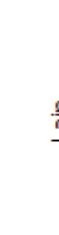 & \\
\hline & & & $\mathrm{F}$ & $\%$ & $F$ & $\%$ & $F$ & $\%$ & F $\quad \%$ & $\mathrm{~F}$ & $\%$ & $\mathrm{~F}$ & $\%$ & $\mathrm{~F}$ & $\%$ \\
\hline \multirow[t]{2}{*}{1} & $\begin{array}{l}\text { Tejoyuwono, } \\
\text { A. A. T., et al }\end{array}$ & 2020 & V & 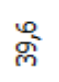 & 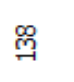 & $\stackrel{m}{m}$ & $\stackrel{\sim}{N}$ & $\stackrel{2}{2}$ & $\vec{F}$ & ๗ & $\stackrel{6}{6}$ & $\bullet$ & $\cong$ & ని & ํㅗㅁ \\
\hline & $\begin{array}{l}\text { Total } \\
\text { responden }\end{array}$ & & & & & & & 36 & 61 & & & & & & \\
\hline
\end{tabular}




\section{Prosiding Seminar Nasional Kesehatan \\ Lembaga Penelitian dan Pengabdian Masyarakat Universitas Muhammadiyah Pekajangan Pekalongan}

Berdasarkan (Tabel 4.9) didapatkan bahwa sebelum menyentuh makanan $142(39,6)$, sebelum pulang ke rumah 138 (38), setelah menyentuh mata, hidung, bibir $28(7,5)$, setelah batuk dan bersin $4(1,1)$, setelah mengerjakan pekerjaan rumah $23(6,6)$, setelah menggunakan toilet $6(1,7)$ dan lain $20(5,5)$.

3. Aktivitas fisik masyarakat di masa pandemi Covid-19

Tabel 4.10 Hasil Analisis Literature Review Aktivitas Fisik Masyarakat di Masa Pandemi Covid-19

\begin{tabular}{|c|c|c|c|c|c|c|c|c|c|c|}
\hline \multicolumn{3}{|c|}{ Artikel } & \multicolumn{8}{|c|}{ Aktivitas fisik } \\
\hline \multirow[t]{2}{*}{ No } & \multirow[t]{2}{*}{ Penulis } & \multirow[t]{2}{*}{ Tahun } & \multicolumn{2}{|c|}{$\begin{array}{l}\text { Tidak } \\
\text { pernah }\end{array}$} & \multicolumn{2}{|c|}{ Jarang } & \multicolumn{2}{|c|}{ Sering } & \multicolumn{2}{|c|}{ Selalu } \\
\hline & & & $\mathrm{F}$ & $\%$ & $\mathrm{~F}$ & $\%$ & $\mathrm{~F}$ & $\%$ & $\mathrm{~F}$ & $\%$ \\
\hline 1 & $\begin{array}{c}\text { Karuniawati, B., \& Putrianti, } \\
\text { B. }\end{array}$ & 2020 & NM & NM & NM & NM & NM & NM & NM & NM \\
\hline 2 & Putri, R. M., et al & 2020 & 20 & 18,5 & 41 & 38 & 32 & 29,6 & 15 & 13,9 \\
\hline & otal masing-masing aktivitas $f$ & & 20 & 18,5 & 41 & 38 & 32 & 29,6 & 15 & 13,9 \\
\hline
\end{tabular}

Berdasarkan (Tabel 4.10) didapatkan bahwa tidak pernah $20(18,5)$, jarang $41(38)$, sering $32(29,6)$ dan $15(13,9)$ selalu melakukan aktivitas fisik.

Tabel 4.11 Hasil Analisis Literature Review Aktivitas Fisik Masyarakat di Masa Pandemi Covid-19

\begin{tabular}{|c|c|c|c|c|c|c|}
\hline \multirow[t]{3}{*}{ No } & \multicolumn{2}{|l|}{ Artikel } & \multicolumn{4}{|c|}{ Aktivitas fisik } \\
\hline & \multirow[t]{2}{*}{ Penulis } & \multirow[t]{2}{*}{ Tahun } & \multicolumn{2}{|c|}{150 menit/minggu } & \multicolumn{2}{|c|}{$\begin{array}{c}\text { Tidak melakukan } \\
\text { aktivitas fisik }\end{array}$} \\
\hline & & & $\mathrm{F}$ & $\%$ & $\mathrm{~F}$ & $\%$ \\
\hline 1 & Tejoyuwono,A.A.T., et al & 2020 & 199 & 55,1 & 162 & 44,9 \\
\hline
\end{tabular}

Berdasarkan (Tabel 4.11) di dapatkan bahwa melakukan aktivitas fisik 150menit/minggu $199(55,1)$, dan $162(44,9)$ tidak melakukan aktivitas fisik.

Tabel 4.12 Hasil Analisis Literature Review Aktivitas Fisik Masyarakat di Masa Pandemi Covid-19

\begin{tabular}{|c|c|c|c|c|c|c|c|c|}
\hline \multirow{3}{*}{\multicolumn{2}{|c|}{$\begin{array}{l}\text { Artikel } \\
\text { Penulis }\end{array}$}} & \multirow{3}{*}{$\begin{array}{c}\text { Tahu } \\
\mathrm{n}\end{array}$} & \multicolumn{6}{|c|}{ Aktivitas fisik } \\
\hline & & & \multicolumn{2}{|c|}{ Tidak pernah } & \multicolumn{2}{|c|}{$<3$ kali seminggu } & \multicolumn{2}{|c|}{$>3$ kali seminggu } \\
\hline & & & $\mathrm{F}$ & $\%$ & $\mathrm{~F}$ & $\%$ & $\mathrm{~F}$ & $\%$ \\
\hline 1 & Utama, L. J & 2020 & 33 & 0,7 & 99 & 1,9 & 59 & 1,1 \\
\hline 2 & Atmaja, T. F. A., et al & 2020 & 9 & 0,1 & 3.861 & 72 & 1.303 & 24,2 \\
\hline \multicolumn{3}{|c|}{ Total masing-masing aktivitas fisik } & 42 & 0,8 & 3.960 & 73,8 & 1.362 & 25,4 \\
\hline \multicolumn{3}{|c|}{ Total responden } & \multicolumn{6}{|c|}{5.364} \\
\hline
\end{tabular}




\section{Prosiding Seminar Nasional Kesehatan Lembaga Penelitian dan Pengabdian Masyarakat Universitas Muhammadiyah Pekajangan Pekalongan}

Berdasarkan (Tabel 4.12) di dapatkan bahwa tidak pernah $42(0,8), 3.960$ $(73,8)$ melakukan aktivitas fisik <3 kali seminggu dan $1.362(25,4)$ melakukan aktivitas fisik $>3$ kali seminggu.

4. Konsumsi buah dan sayur masyarakat di masa pandemi Covid-19

Tabel 4. 13 Hasil Analisis Literature Review Konsumsi Buah dan Sayur Masyarakat di Masa Pandemi Covid-19

\begin{tabular}{|c|c|c|c|c|c|c|c|c|c|c|c|c|}
\hline \multicolumn{3}{|c|}{ Artikel } & \multicolumn{10}{|c|}{ Konsumsi sayur dan buah } \\
\hline \multirow[t]{2}{*}{ No } & \multirow[t]{2}{*}{ Penulis } & \multirow[t]{2}{*}{ Tahun } & \multicolumn{2}{|c|}{$\begin{array}{l}\text { Tidak } \\
\text { pernah }\end{array}$} & \multicolumn{2}{|c|}{ Jarang } & \multicolumn{2}{|c|}{$\begin{array}{c}\text { Kadang- } \\
\text { kadang }\end{array}$} & \multicolumn{2}{|c|}{ Sering } & \multicolumn{2}{|c|}{ Selalu } \\
\hline & & & $\mathrm{F}$ & $\%$ & $\mathrm{~F}$ & $\%$ & $\mathrm{~F}$ & $\%$ & $\mathrm{~F}$ & $\%$ & $\mathrm{~F}$ & $\%$ \\
\hline 1 & $\begin{array}{l}\text { Karuniawati } \\
\text {, B., \& } \\
\text { Putrianti, B. }\end{array}$ & 2020 & NM & NM & NM & NM & NM & NM & NM & NM & NM & NM \\
\hline 2 & $\begin{array}{l}\text { Atmaja, T. } \\
\text { F. A., et al }\end{array}$ & 2020 & 14 & 0,20 & 370 & 5.5 & $\begin{array}{c}3.30 \\
9\end{array}$ & 49,7 & NM & NM & $\begin{array}{c}2.86 \\
4\end{array}$ & 43 \\
\hline 3 & $\begin{array}{c}\text { Putri, R. M., } \\
\text { et al }\end{array}$ & 2020 & 2 & 0,03 & 50 & $\begin{array}{c}0,7 \\
5\end{array}$ & NM & NM & 41 & 0,60 & 15 & 0,22 \\
\hline \multicolumn{3}{|c|}{$\begin{array}{c}\text { Total masing-masing } \\
\text { konsumsi buah dan } \\
\text { sayur }\end{array}$} & 16 & 0,20 & 420 & $\begin{array}{c}6,3 \\
0\end{array}$ & $\begin{array}{c}3.30 \\
9\end{array}$ & 49,7 & 41 & 0,60 & $\begin{array}{c}2.87 \\
9\end{array}$ & 43,2 \\
\hline \multicolumn{3}{|c|}{ Total responden } & \multicolumn{10}{|c|}{6.665} \\
\hline
\end{tabular}

Berdasarkan (Tabel 4.13) didapatkan bahwa tidak pernah $16(0,20)$, jarang $420(6,30)$, kadang-kadang $3.309(49,7)$, sering $41(0,60)$ dan $2.879(43,2)$ selalu konsumsi buah dan sayur.

Tabel 4.14 Hasil Analisis Literature Review Konsumsi Buah dan Sayur Masyarakat di Masa Pandemi Covid-19

\begin{tabular}{|c|c|c|c|c|c|c|c|c|}
\hline \multicolumn{3}{|c|}{ Artikel } & \multicolumn{6}{|c|}{ Konsumsi sayur dan buah } \\
\hline \multirow[t]{2}{*}{ No } & \multirow[t]{2}{*}{ Penulis } & \multirow[t]{2}{*}{ Tahun } & \multicolumn{2}{|c|}{ Setiap hari } & \multicolumn{2}{|c|}{ Jarang } & \multicolumn{2}{|c|}{ Kadang-kadang } \\
\hline & & & $\mathrm{F}$ & $\%$ & $\mathrm{~F}$ & $\%$ & $\mathrm{~F}$ & $\%$ \\
\hline 1 & Utama, L. J & 2020 & 75 & 39,27 & 20 & 10,47 & 96 & 50,26 \\
\hline \multicolumn{3}{|c|}{$\begin{array}{c}\text { Total masing-masing konsumsi buah } \\
\text { dan sayur }\end{array}$} & 75 & 39,27 & 20 & 10,47 & 96 & 50,26 \\
\hline \multicolumn{3}{|c|}{ Total responden } & \multicolumn{6}{|c|}{191} \\
\hline
\end{tabular}

Berdasarkan (Tabel 4.14) didapatkan bahwa $75(39,27)$ setiap hari, jarang $20(10,47)$, dan $96(50,26)$ kadang-kadang konsumsi buah dan sayur.

Tabel 4.15 Hasil Analisis Literature ReviewKonsumsi Buah dan Sayur Masyarakat di Masa Pandemi Covid-19

\begin{tabular}{|c|c|c|c|c|c|c|}
\hline \multirow[t]{3}{*}{ No } & Artikel & & \multicolumn{4}{|c|}{ Konsumsi buah dan sayur } \\
\hline & \multirow[t]{2}{*}{ Penulis } & \multirow[t]{2}{*}{ Tahun } & \multicolumn{2}{|c|}{$\begin{array}{l}\text { Mengkonsumsi buah } \\
\text { dan sayur }\end{array}$} & \multicolumn{2}{|c|}{$\begin{array}{c}\text { Tidak mengkonsumsi } \\
\text { buah dan sayur }\end{array}$} \\
\hline & & & $\mathrm{F}$ & $\%$ & $\mathrm{~F}$ & $\%$ \\
\hline 1 & Tejoyuwono,A.A.T., et al & 2020 & 289 & 80,0 & 72 & 20,0 \\
\hline & Total responden & \multicolumn{5}{|c|}{361} \\
\hline
\end{tabular}




\section{Prosiding Seminar Nasional Kesehatan Lembaga Penelitian dan Pengabdian Masyarakat Universitas Muhammadiyah Pekajangan Pekalongan}

Berdasarkan (Tabel 4.15) didapatkan bahwa $289(80,0)$ mengkonsumsi buah dan sayur, dan $72(20,0)$ tidak mengkonsumsi buah dan sayur.

5. Penggunaan masker masyarakat di masa pandemi Covid-19

Tabel 4. 16 Hasil Analisis Literature Review Penggunaan Masker Masyarakat di Masa Pandemi Covid-19

\begin{tabular}{|c|c|c|c|c|c|c|c|c|c|c|}
\hline \multicolumn{3}{|c|}{ Artikel } & \multicolumn{8}{|c|}{ Penggunaan Masker } \\
\hline \multirow[t]{2}{*}{ No } & \multirow[t]{2}{*}{ Penulis } & \multirow[t]{2}{*}{ Tahun } & \multicolumn{2}{|c|}{$\begin{array}{l}\text { Tidak } \\
\text { pernah }\end{array}$} & \multicolumn{2}{|c|}{ Jarang } & \multicolumn{2}{|c|}{ Sering } & \multicolumn{2}{|c|}{ Selalu } \\
\hline & & & $\mathrm{F}$ & $\%$ & $\mathrm{~F}$ & $\%$ & $\mathrm{~F}$ & $\%$ & $\mathrm{~F}$ & $\%$ \\
\hline 1 & $\begin{array}{l}\text { Karuniawati, B., \& } \\
\text { Putrianti, B. }\end{array}$ & 2020 & NM & NM & NM & NM & 3 & 1,6 & 68 & 38 \\
\hline 2 & Atmaja, T. F. A., et al & 2020 & NM & NM & NM & NM & NM & NM & NM & NM \\
\hline 3 & $\begin{array}{l}\text { Tejoyuwono, A. A. T., et } \\
\text { al }\end{array}$ & 2020 & NM & NM & NM & NM & NM & NM & NM & NM \\
\hline 4 & Putri, R. M., et al & 2020 & 7 & 3,9 & 35 & $\begin{array}{c}19, \\
5\end{array}$ & 32 & 18 & 34 & 19 \\
\hline & $\begin{array}{c}\text { Total masing-masing pengg } \\
\text { masker }\end{array}$ & an & 7 & 4 & 35 & $\begin{array}{c}19, \\
5\end{array}$ & 35 & 19,5 & 102 & 57 \\
\hline & Total responden & & & & & & 179 & & & \\
\hline
\end{tabular}

Berdasarkan (Tabel 4.16) di dapatkan bahwa 7 (4) tidak pernah, $35(19,5)$ jarang, 35 (19,5) sering dan 102 (57) selalu menggunakan masker.

Tabel 4.17 Hasil Analisis Literature Review Penggunaan Masker Masyarakat di Masa Pandemi Covid-19

\begin{tabular}{|c|c|c|c|c|c|c|}
\hline \multirow[t]{2}{*}{ No } & \multicolumn{2}{|c|}{ Artikel } & \multicolumn{4}{|c|}{ Penggunaan masker } \\
\hline & \multirow[t]{2}{*}{ Penulis } & \multirow[t]{2}{*}{ Tahun } & \multicolumn{2}{|c|}{$\overline{Y a}$} & \multicolumn{2}{|c|}{ Tidak } \\
\hline & & & $\mathrm{F}$ & $\%$ & $\mathrm{~F}$ & $\%$ \\
\hline 1 & Utama, L. J & 2020 & 188 & 98,4 & 3 & 1,6 \\
\hline & Total responden & & & 191 & & \\
\hline
\end{tabular}

Berdasarkan (Tabel 4.17) di dapatkan bahwa $188(98,4)$ ya dan $3(1,6)$ tidak menggunakan masker.

6. Jaga jarak masyarakat di masa pandemi Covid-19

Tabel 4. 18 Hasil Analisis Literature Review Jaga Jarak Masyarakat di Masa Pandemi Covid-19

\begin{tabular}{|c|c|c|c|c|c|c|c|c|c|c|}
\hline \multicolumn{3}{|c|}{ Artikel } & \multicolumn{8}{|c|}{ Jaga Jarak } \\
\hline \multirow[t]{2}{*}{ No } & \multirow{2}{*}{ Penulis } & \multirow[t]{2}{*}{ Tahun } & \multicolumn{2}{|c|}{ Tidak pernah } & \multicolumn{2}{|c|}{ Kadang-kadang } & \multicolumn{2}{|c|}{ Sering } & \multicolumn{2}{|c|}{ Selalu } \\
\hline & & & $\mathrm{F}$ & $\%$ & $\mathrm{~F}$ & $\%$ & $\mathrm{~F}$ & $\%$ & $\mathrm{~F}$ & $\%$ \\
\hline 1 & Karuniawati, B., \& Putrianti, B. & 2020 & 1 & 0,2 & 6 & 1,3 & 34 & 8,0 & 30 & 7,0 \\
\hline 2 & Utama, L. J & 2020 & NM & NM & NM & NM & NM & NM & NM & NM \\
\hline 3 & Atmaja, T. F. A., et al & 2020 & NM & NM & NM & NM & NM & NM & NM & NM \\
\hline 4 & Tejoyuwono, A. A. T., et al & 2020 & 36 & 8,3 & NM & NM & NM & NM & 325 & 75,2 \\
\hline 5 & Putri, R.M., et al & 2020 & NM & NM & NM & NM & NM & NM & NM & NM \\
\hline Tot & masing-masing jaga jarak & & 37 & 8,6 & 6 & 1,3 & 34 & 8,0 & 355 & 82,1 \\
\hline & Total responden & & & & & 432 & & & & \\
\hline
\end{tabular}




\section{Prosiding Seminar Nasional Kesehatan $\mid 2021$ \\ Lembaga Penelitian dan Pengabdian Masyarakat Universitas Muhammadiyah Pekajangan Pekalongan}

Berdasarkan literature review yang membahas mengenai jaga jarak didapatkan hasil (Table 4.18) bahwa tidak pernah $37(8,6)$, kadang-kadang 6 $(1,3)$, sering $34(8,0)$, dan selalu $355(82,1)$.

\section{Pembahasan}

1. Karakteristik responden

Berdasarkan karakteristik sebagian besar usia responden menunjukkan bahwa sebagian besar responden berumur 20-35 tahun sebanyak 249 (67,3\%) responden. Dalam penelitian ini usia reproduksi sehat mendominasi usia responden. Seiring dengan bertambahnya usia maka akan terjadi perubahan perilaku dimana mereka akan sulit menerima informasi, cenderung mengabaikan PHBS dan mudah terkena penyakit. Hal ini didukung oleh penelitian yang dilakukan (Prihatini., et al.2018) yang mengatakan bahwa usia memiliki pengaruh secara signifikan dalam mempengaruhi PHBS.

Hasil karakteristik responden kategori jenis kelamin, sebagian besar responden berjenis kelamin perempuan sebanyak $5.249(72,7 \%)$ responden. Hal ini sejalan dengan Teori Green dalam bahwa faktor demografi (jenis kelamin) mempengaruhi perilaku kesehatan.

Berdasarkan karakteristik pendidikan responden diketahui bahwa sebagian besar $4.394(60,4 \%)$ responden memiliki status pendidikan Sekolah Menengah Pertama (SMP). Hal ini mempengaruhi kualitas PHBS, karena pendidikan yang rendah menjadikan responden sulit memahami akan pentingnya higyene perorangan dan sanitasi lingkungan untuk mecegah terjangkitnya penyakit menular, dengan sulit memahami arti penting PHBS menyebabkan mereka tidak perduli dengan upaya pencegahan penyakit menular (Sander, 2005) dalam (Amalia, 2009).

\section{Cuci tangan masyarakat di masa pandemi Covid-19}

Berdasarkan hasil literature review artikel menunjukan bahwa 5.329 (82,5\%) selalu cuci tangan pakai sabun, $38(35,3 \%)$ sering cuci tangan dengan 6 langkah, $59(83,1 \%)$ selalu cuci tangan pakai sabun setelah keluar rumah, $54(76,1 \%)$ selalu cuci tangan dengan sabun sebelum makan, 35 (49,3\%) selalu cuci tangan dengan sabun setelah memegang uang, dan 142 (39,6\%) cuci tangan sebelum menyentuh makanan. Hasil literature review artikel ini menunjukan bahwa masyarakat sudah melakukan PHBS untuk pencegahan Covid-19 yaitu dengan selalu mencuci tangan. Cuci tangan merupakan salah satu cara yang dianjurkan oleh Kemenkes dalam pencegahan penularan virus Covid-19, karena tangan yang bersih dapat mengurangi resiko masuknya virus ke dalam tubuh. Menurut (Kemenkes. 2020) mencuci tangan sesering mungkin dan dengan cara yang tepat (setidaknya selama 40 detik) adalah salah satu langkah paling pentig untuk mencegah infeksi Covid-19.

Hasil literature review artikel ini sejalan dengan (Anggraini., et al. 2020) bahwa masyarakat kota Binjai pada masa pandemi Covid-19 sudah menerapkan PHBS cuci tangan dalam kehidupan sehari-hari sehingga dapat mencegah Covid19. 


\section{Prosiding Seminar Nasional Kesehatan $\mid 2021$ Lembaga Penelitian dan Pengabdian Masyarakat Universitas Muhammadiyah Pekajangan Pekalongan}

3. Aktivitas fisik masyarakat di masa pandemi Covid-19

Menurut (Keputusan Menteri Kesehatan Republik Indonesia .2020) bahwa prinsip pencegahan penularan Covid-19 pada individu dilakukan dengan menghindari masuknya virus melalui ketiga pintu masuk dan meningkatkan daya tahan tubuh dengan menerapkan PHBS seperti aktivitas fisik minimal 30 menit sehari.

Berdasarkan hasil literature review artikel menunjukan bahwa 41 (38\%) jarang melakukan aktivitas fisik, 199 (55,1\%) melakukan aktivitas fisik 150menit/minggu, dan 3.960 (73,8\%) melakukan aktivitas fisik <3kali seminggu, hal ini berbeda dengan penelitian (Sunardi, J., et al. 2020) bahwa didapatkan 126 responden $(29,65 \%)$ pada kriteria tinggi melakukan aktivitas fisik.

4. Konsumsi buah dan sayur masyarakat di masa pandemi Covid-19

Berdasarkan hasil literature review artikel menunjukan bahwa 3.309 $(49,7 \%)$ responden kadang-kadang konsumsi buah dan sayur, 96 (50,26\%) kadang-kadang konsumsi buah dan sayur, dan 289 (80,0\%) mengkonsumsi buah dan sayur. Hasil ini sejalan dengan penelitian (Sunardi, J., et al. 2020) bahwa didapatkan 161 respoden $(37,88 \%)$ dalam kategori cukup mengkonsumsi makanan dan minuman sehat.

\section{Penggunaan masker}

Mengenakan masker dengan benar dapat secara efektif memblokir tetesan pernapasan yang berguna untuk mencegah virus masuk ke dalam tubuh. Berdasarkan hasil literature review artikel menunjukan bahwa sebagian besar responden 102 (57\%) responden selalu menggunakan masker, dan 188 (98,4\%) responden menggunakan masker. Memakai masker merupakah salah satu cara yang di anjurkan pemerintah untuk pencegahan penularan Covid-19. Menurut (Dinas Kesehatan Sleman.2020) Salah satu ndikator PHBS adalah menggunakan masker dapat mencegah penularan virus dari orang lain pada kita atau sebaliknya, karena virus corona dapat menular melalui droplet atau cairan yang keluar bersamaan ketika batuk, bersin atau percikan air liur ketika berbicara.

Hasil literature review artikel ini sejalan dengan penelitian (Yanti, Ni Putu. E. D., et al.2020) bahwa responden di masa pandemi selalu menggunakan masker sebanyak 137 (91,33\%) responden.

\section{Jaga Jarak}

Berdasarkan hasil literature review artikel menunjukan bahwa 37 (8,6\%) tidak pernah jaga jarak, 6 (1,3\%) kadang-kadang, $34(8,0 \%)$ dan selalu 355 $(82,1 \%)$ responden jaga jarak. Menurut (Dinas Kesehatan Sleman. 2020) PHBS menjaga jarak dengan orang lain minimal 2 meter, karena berkerumun sangat beresiko menularkan virus. Menurut (Kemenkes.2020) menjaga jarak dengan orang lain berguna untuk menghindari terkena droplet dari orang yang batuk dan bersin.

Hasil literature review artikel ini sejalan dengan penelitian (Yanti, Ni Putu. E. D., et al.2020) bahwa responden selalu menjaga jarak 107 (71,33\%) responden. 


\section{Prosiding Seminar Nasional Kesehatan \\ Lembaga Penelitian dan Pengabdian Masyarakat Universitas Muhammadiyah Pekajangan Pekalongan}

\section{Kesimpulan}

Simpulan dari penelitian literature review ini adalah sebagai berikut :

1. Karakteristik responden

Berdasarkan karakteristik usia sebagian besar responden 249 (67,3\%) yaitu usia 20-35 tahun. Berdasarkan jenis kelamin didapatkan sebagian besar responden ber jenis kelamin perempuan yaitu $5.249 \quad(72,7 \%)$ responden.Sedangkan berdasarkan karakteristik pendidikan sebagian besar responden berpendidikan SMP sebanyak 4.394 (60,4\%) responden.

2. Gambaran cuci tangan masyarakat di masa pandemi Covid-19 yaitu 5.329 $(82,5 \%)$ selalu cuci tangan pakai sabun, 38 (35,3\%) sering cuci tangan dengan 6 langkah, $59(83,1 \%)$ selalu cuci tangan pakai sabun setelah keluar rumah, $54(76,1 \%)$ selalu cuci tangan dengan sabun sebelum makan, $35(49,3 \%)$ selalu cuci tangan dengan sabun setelah memegang uang, dan $142(39,6 \%)$ cuci tangan sebelum menyentuh makanan.

3. Gambaran aktivitas fisik masyarakat di masa pandemi Covid-19 yaitu 41 (38\%) jarang melakukan aktivitas fisik, 199 (55,1\%) melakukan aktivitas fisik 150menit/minggu, dan $3.960(73,8 \%)$ melakukan aktivitas fisik <3kali seminggu.

4. Gambaran konsumsi buah dan sayur masyarakat di masa pandemi Covid-19 yaitu $3.309(49,7 \%)$ responden kadang-kadang konsumsi buah dan sayur, $96(50,26 \%)$ kadang-kadang konsumsi buah dan sayur, dan $289(80,0 \%)$ mengkonsumsi buah dan sayur.

5. Gambaran penggunaan masker masyarakat di masa pandemi Covid-19 didapatkan hasil $102(57 \%)$ responden selalu menggunakan masker, dan $188(98,4 \%)$ responden menggunakan masker.

6. Gambaran jaga jarak masyarakat di masa pandemi Covid-19 yaitu 37 $(8,6 \%)$ tidak pernah jaga jarak, $6(1,3 \%)$ kadang-kadang, $34(8,0 \%)$ dan selalu $355(82,1 \%)$ responden jaga jarak.

\section{Referensi}

Anggraini, D. T., et al., 2020. Gambaran Promosi PHBS dalam Mendukung Gaya Hidup Sehat Masyarakat Kota Binjai pada Masa Pandemic Covid-19 Tahun 2020. Medan : Jurnal menara medika.

Atmadja, T. F. A., Yunianto, A. E., Yuliantini, E., Haya, M., Faridi, A., \& Suryana, S. (2020). Gambaran sikap dan gaya hidup sehat masyarakat Indonesia selama pandemi Covid-19. AcTion: Aceh Nutrition Journal, 5(2), 195-202.

Dinas Kesehatan. 2020. Perilaku Hidup Bersih dan Sehat Cegah Covid19.https://dinkes, slemankab.go.id/perilaku-hidup-bersih-dan-sehat-cegah-covid19.html. Diakses tanggal 4 Maret 2021.Pukul 17.50 WIB. 


\section{Prosiding Seminar Nasional Kesehatan \\ Lembaga Penelitian dan Pengabdian Masyarakat Universitas Muhammadiyah Pekajangan Pekalongan}

Amalia, Imanda.2009. Hubungan Antara Pendidikan, Pendapatan dan Perilaku Hidup Bersih dan Sehat (PHBS) pada Pedagang Hidangan Istimewa Kampung (HIK) di Pasar Kliwon dan Jebres Kota Surakarta. Surakarta. Universitas Muhamadiyah Surakarta.

Isbaniyah, F., Saputro, D. D., et al. 2020.Pedoman Pencegahan dan Pengendalian Coronavirus Disease (COVID-19).Jakarta : KemenkesRI \& P2P.

Karuniawati, B., \& Putrianti, B. (2020).Gambaran perilaku hidup bersih dan sehat (phbs) dalam pencegahan penularan covid-19. Jurnal Kesehatan Karya Husada, 8(2), 34-53.

Kementrian Kesehatan Republik Indonesia.2020.Cegah Virus Corona Jaga Kesehatan dengan GERMAS.https://promkes.kemkes.go.id/cegah-virus-corona-jagakesehatan-dengan-germas. Diakses tanggal 28 Febuari 2020.Pukul16.42 WIB.

Kementrian Kesehatan Republik Indonesia. 2020. Situasi Covid-19. https://www.kemenkes.go.id.Diakses.tanggal 18 Febuari 2021.Pukul 17:59 WIB.

Kementrian Kesehatan Republik Indonesia.2011.Pedoman Pembinaan Perilaku Hidup Bersih dan Sehat (PHBS). Jakarta : Kementrian Kesehatan Republik Indonesia.

Kementrian Kesehatan Republik Indonesia.2020. Protokol Kesehatan Bagi Masyarakat di Tempat dan Fasilitas Umum dalam Rangka Peencegahan dan Pengendalian Corona Virus Disease 2019 (Covid-19).Jakarta : Kemenkes RI.

Kementrian Kesehatan Republik Indonesia.2020. Panduan Cuci Tangan Pakai Sabun. Jakarta : Kemenkes.

Maryuni, A. 2013.Perilaku Hidup Bersih dan Sehat (PHBS).Jakarta : CV.Trans info medi.

Mulyadi, H. D., Aziza, L. N., \& Akbar, M.2020 .Pentingnya Penerapan PHBS dalam Menghadapi Pandemi Covid-19 di Lingkungan Masyarakat. Semarang : Universitas Negeri Semarang.

Prihatini, G. S., et al. 2018. Faktor-Faktor yang Mempengaruhi Tingkat Peilaku Hidup Bersih dan Sehat pada Tatanan Rumah Tangga di Wilayah Kerja Pukesmas Poned X. Saintika Medika, 14(1), 7-14.

Proverawati, A., Rahmawati, E. 2017.PHBS Periaku Hidup Bersih \& Sehat. Jakarta : Nuha Medika.

Putri, Ronasari Mahaji., et al. 2021. Gambaran Perilaku Mahasiswa dalam Pencegahan Penularan Corona Virus Disease (Covid-19). Jambi : Jurnal Akademka Baiturrahim Jambi.

Razi, F., Yulianty, V., et al. 2020. Bunga Rampai Covid-19 : Buku Kesehatan Mandiri untuk Sahabat\#Dirumahaja. Depok : PD Prokam. 


\section{Prosiding Seminar Nasional Kesehatan Lembaga Penelitian dan Pengabdian Masyarakat Universitas Muhammadiyah Pekajangan Pekalongan}

Sugihantono, A.,Burhan, E., et al. 2020. Pedoman Pencegahan dan Pengendalian Coronavirus Disease (COVID-19). Jakarta : Kementrian Kesehatan Republik Indonesia.

Sunardi, J., \& Kriswanto, E. S. (2020). Perilaku hidup bersih dan sehat mahasiswa pendidikan olahraga Universitas Negeri Yogyakarta saat pandemi Covid19. Jurnal Pendidikan Jasmani Indonesia, 16(2), 156-167.

Tejoyuwono, A. A. T., Nugraha, R. P., \& Fahdi, F. K. (2021). Phbs Implementation And Personal Factors Of Medical Students During The Covid-19 Pandemic Period. European Journal of Molecular \& Clinical Medicine, 710$), 1499-1510$.

Tejokusumo, B.2014.Dinamika Masyarakat sebagai Sumber Belajar Ilmu Pengetahuan Sosial. Malang. Goedokasi Volume III Nomor 1.

Utama, L. J. (2020). Gaya Hidup Mayarakat Nusa Tenggara Timur Dalam Menghadapi Pandemi Corona Virus Disease 19 (Covid-19). An-Nadaa: Jurnal Kesehatan Masyarakat, 71$), 34-40$.

Yanti, N. P. E. D., Nugraha, I. M. A. D. P., Wisnawa, G. A., Agustina, N. P. D., \& Diantari, N. P. A. (2020). Gambaran pengetahuan masyarakat tentang covid-19 dan perilaku masyarakat di masa pandemi covid-19. Jurnal Keperawatan Jiwa, 8(3), 485-490

ZA, Safrizal., Putra D. I., et al. 2020. Pedoman Umum Menghadapi Covid-19 Bagi Pemerintah Daerah. Tim kerja kemenkes. 